\title{
POLICY REVIEW ON ISLAMIC EDUCATION IN THE OLD ORDER ERA IN INDONESIA
}

\author{
Irwansyah Suwahyu1, Nurhilaliyah ${ }^{2}$ \\ 1,2Universitas Negeri Makassar \\ 1,2Jl. Daeng Tata Raya, JPTE FT UNM, Kampus II Parangtambung Makassar \\ Email: irwansyahsuwahyu@unm.ac.id ${ }^{1}$, nurhilaliyah@unm.ac.id ${ }^{2}$
}

\begin{abstract}
:
This article explains about some policies of Indonesian government in the old order era to the Islamic education. This study is a library research. The data obtained through the documents were analyzed by using content analysis. The research findings indicated that the Islamic education in the early of Indonesian's independence day was not the concern of Indonesian government, whether it was a general policy as in the department of religious affairs or specifically as a policy in the study of religious education in schools. After PKI's incident, the Islamic education received serious attention from the government such as policy requiring religious learning at every level of education. It was intended to eliminate the influence of the communist mind.
\end{abstract}

\begin{abstract}
Abstrak:
Artikel ini menjelaskan tentang beberapa kebijakan pemerintah Indonesia di era orde lama terhadap pendidikan Islam. Penelitian ini adalah penelitian kepustakaan. Data yang diperoleh melalui dokumen dianalisis dengan menggunakan analisis isi. Temuan penelitian menunjukkan bahwa pendidikan Islam di awal hari kemerdekaan Indonesia bukanlah urusan pemerintah Indonesia, apakah itu kebijakan umum seperti di departemen urusan agama atau secara khusus sebagai kebijakan dalam studi pendidikan agama di sekolah. Setelah kejadian PKI, pendidikan Islam mendapat perhatian serius dari pemerintah seperti kebijakan yang mengharuskan pembelajaran agama di setiap tingkat pendidikan. Itu dimaksudkan untuk menghilangkan pengaruh pikiran komunis.
\end{abstract}

\section{Keywords:}

Policy, Islamic Education in Indonesia, Old Order Era

How to Cite: Suwahyu, I. \& Nurhilaliyah. (2020). Policy Review on Islamic Education in the Old Order Era in Indonesia. Lentera Pendidikan : Jurnal Ilmu Tarbiyah dan Keguruan, 23(1), 86-97. https://doi.org/10.24252/lp.2020v23n1i8.

\section{INTRODUCTION}

The development of Indonesian government started from independence proclamation on August 17th, 1945. The independence proclamation is an important milestone in Indonesian history. As the independent nation, the Indonesian needs to construct a national life system based on Pancasila and 1945 constitution (UUD 1945) (Fadli \& Kumalasari, 2019: 157). Among those life systems, an educational system is composed which is required by all Indonesian citizens (Ismail, 2016: 143-143). The educational implementation has to be conducted by both the society and the government, or at least getting help from the government (Muzammil, 2016). The development of national education is a joint effort of all components of government and society carried out in a planned and systematic way to realize students to actively develop their potential to 
have spiritual strength, self-control, personality, intelligence, noble character, and the skills needed by themselves, the community, nation, and state. Based on the mandate of the law, education has a strategic position to improve the quality and dignity of every citizen as a dignified and sovereign nation (Irianto, 2011).

In a study conducted by Kosim (2014) entitled, "Islamic Religious Education Policy in schools during the old order". Here it is explained that the PAI subjects are elective subjects that can be followed by students or not. Another study conducted by Ahmad (2018), "Analysis of Islamic Religious Education Policy in Public Schools in the Dutch, Japanese and Old Order". This study also found a lack of government attention to religious education in schools.

Indonesia, as a country that continues to develop, requires a step forward in the field of education. After the independence in 1945, Indonesia began to fix all aspects of national development. Indonesian leaders at that time saw the importance of education for the integrity of the nation which was still vulnerable to the influent threat of the invaders, who still seemed unwilling to release Indonesia from its grasp.

Indonesian history records that in its development, education in Indonesia experienced many changes to achieve a national ideal that is to educate the nation's life. The changes occurring in education are the basic changes which mean the changes related to the adjustment of educational policy with the basis and ideals of the independent nation (Rifa'i, 2016: 122). Therefore, in order to adjust it with the Indonesian ideals, the education got changes, especially in the foundation of education philosophy, the aims of education, the systems of education, and the opportunity of learning given to the Indonesian society, considering Pancasila as the nation basis and philosophy, as stated in the opening of 1945 constitution that becomes the main basis of Indonesian education, even though about 1945-1950 and 1950-1966 the Indonesia basic constitution had been changed within a fairly quick time (Mestoko, 1985).

In order to implement the national basis of 1945 constitution, the Indonesia government at that time, known with the reign of the Old Order under the leadership of Ir. Soekarno, formulated various regulations as the government policy as the national education. Then, the Islamic education was also inseparable from the policy at that time. In brief, education policy is understandable through the opinions expressed by some experts, such as: according to Munadi and Barnawi, education policy is a decision taken jointly between the government and the actors (policy) outside the government, and considering the factors that affect to be implemented or not implemented in the field of education for all societies (Mahfud, 2013). This definition refers to the formulation in which the education policy is the public policy in the field of education (Nugroho, 2008).

There are several periods in the long journey of education in this nation, starting from the era of the old order, the new order, and reformation. But, in this article, the writer focused on discussing the condition of Islamic education in the old order era. Indonesia, a country with a majority Muslim population, should pay attention to every policy in the field of education specifically in Islamic education. That was the reason why the writer is interested to review the policies made by the Indonesian government in the old order era toward Islamic education. 


\section{RESEARCH METHOD}

This research used library research method, namely research that relied on library materials as a source of information to answer the main points of Indonesian government policy toward Islamic education in the old order era. The stages of finding the data were collecting relevant materials such as books and research related to this research. Then, these materials were read, reviewed, recorded, and utilized as best they could. After all the stages were completed, the data were analyzed using content analysis so that conclusions could be drawn regarding the government policies toward the Islamic education in the old order era.

\section{RESULT AND DICUSSION}

\section{Policies and Implementation of Islamic Education in Indonesia in the Old Order}

\section{Policy towards the Ministry of Religion}

There are many definitions about the concept of policy. Thomas Dye defines policy as "... everything that will be implemented or not implemented by the government" (Thomas, 1978). Richard (1974) defines it as ".... the visible products from decisions taken by the figures who can identify themselves with the societys' ideals." Quite different from the previous definitions, Anderson (1979) defines policy as "a behavior pattern directed to the goals which is followed by a person or some people dealing with problem solving."

In the early days of independence, Indonesia government felt that it was necessary to improve the condition of the education. The Indonesia government had conducted character building of Islamic education in particular. Development of the Islamic education formally is entrusted to the ministry of Religious Affairs and the ministry of Education and Culture (Yuningsih, 2015). The Islamic education in Indonesia is initiated through personal and collective contacts between Muslim educators and the education participants (Daulay, 2017). "Islamic education in public schools began to formally regulated by the government in December 1946, before the Islamic education as a substitute for character education that had existed since the days of Japan run its own in each area" (Zuairini, 1992). As a step forward to realize it, Indonesian government made several policies that could correct the education deficiencies that existed in Indonesia after the Dutch and Japanese occupations. When the Department of Religion (formerly the Ministry of Religion) was established on January 3,1946, in a young country, Indonesia, it was a policy that had been predicted from the beginning and was not a 100 percent new department. By establishing the Department of Gamma, several government activities related to religion that had existed since colonial times and the Japanese occupation continued. Likewise, some parts of other departments are included in the department itself (Steenbrink, 1986).

During Dutch colonial era, a religious office was established, with the official name "Kantoor Voor Inlandsche Zaken." Whereas, during Japanese period, it was called "Shumuka" which functioned as a general advisor in religious matters, included assigning staffs in the field of religion and overseeing religious books. In the Dutch era, this office was formed as an advisory office for indigenous cases, which in Japanese time was 
expanded and was the first office headed by a native and all of its Indonesian employees. In Japanese period, this office had branches in all cities of the residencies although it was still under the education department. This office later became the core of the Department of Religion which was established later (Steenbrink, 1986).

From the data presented, it appears that a positive line of religious education policy began with the office of religion in the Japanese era. This policy was very strongly continued by the Ministry of Religion, after 1946. In one of the Memorandum of Islamic Education in Indonesia compiled by the education department of the Ministry of Religion on September 1st, 1956, this was described as follows: (1) Providing religious instruction in public and private schools. (2) Providing general knowledge in Madrasah (Islamic elementary school). (3) Organizing Religious Teacher Education (PGA) and State Islamic Judge Education (PHIN). Steenbrink (1986) in his book also adds that third school is intended to meet the needs of employees of the Department of Religion itself. The first and second types are associated with dualistic education that emerged in Indonesia since the end of the last century. As a result, the Dutch government did not pay attention to existing Islamic educational institutions, so they established their education system. The education system is then referred to as a separate school system with an education system that specifically pays attention to religious education. In Indonesian government, the school system is included in the Ministry of Education and Culture. Therefore, there were indeed stages in the process of education policy by the religious department at that time that would not be much different from the policies that existed in the period before independence.

\section{Policy towards Islamic Higher Education}

In the education context in Indonesia, there is indisputable fact that Islamic education including Islamic higher education is not something new. The situation in Indonesia encouraged the international academics to consider Islamic higher education as an alternative in education innovation and transformation both in terms of material and methodology (Abdullah, 2017: 392). Ali \& Sumedi (2010) stated that the dualism paradigm inherited from the colonial government remains firmly rooted in the world of education in the country. The Indonesian government inherited a dualistic educational system, namely: (1) the education system and teaching in secular public schools; and (2) Islamic education and teaching system that grows and develops among Islamic societies, both those that tend to be traditional-isolative and those that tend to be synthesized. In 1950, there was a historical accident in our world of education, when President Sukarno established the establishment of Gadjah Mada University which was intended for the nationalist group and at the same time established the State Islamic University of Yogyakarta (PTAIN) for the Muslims.

In subsequent developments, the polarization of the two educational institutions has, in turn, formed a broad polarization. Further implications of the polarization that occur are (1) public universities as if they do not belong to the Islamic group; (2) dualism and dichotomy persist even widen; and (3) public schools/colleges are guided by the Ministry of Education and Culture and Islamic Higher Education is under the guidance of 
the Ministry of Religion. At the very least, this reality resulted in the fall of Islamic education into two types of dichotomy or dualism. First, the secular educational dichotomy and Islamic characteristic education; Second, Islamic education is trapped in management dualism, between the management of education under the Ministry of National Education and Islamic education under the Department of Religion. Not to mention, although Islamic educational organizations continue to exist, they still cannot get the full attention of the government. Islamic educational institutions as if left to live "as is" despite the conditions that are very simple and run as possible.

\section{Policy in Schools towards PAI Subject}

The debate over the discourse of Islamic education in schools began when the question was raised about whether religious education (PA) was required or not? Because in Law No.4 in 1950 and Law No. 12 in 1954 constitution, the formulation of religious teaching in public schools was finally listed in chapter XII on "Religious Teaching in Public Schools", article 20 paragraph (1) in state schools held religious lessons, parents determine whether their children follow the lesson or not, and (2) how to hold religious lessons in public schools is regulated in regulations established by the minister of education, teaching, and culture, together with the Minister of Religion (Soebahar, 2013).

The picture of a serious debate can be explored, for example, in the explanation of article 20 (Law No.4/1950 or Law No. 12/1954), many confusing formulations, among others: (a) whether a type of school provides religious instruction which depends on the students' age and their intelligence, (b) adult students may determine whether or not to participate in religious studies, (c) the nature of religious teaching and the number of hours of study determined in the law about the type of school, and (d) religious studies do not affect grade promotion.

Islamic Education (PAI) in private schools is not regulated. It is submitted entirely to the organizers of educational institution. For private schools managed by Islamic organizations, PAI tends to be taught, but for those managed by non-Muslims, PAI will likely be abolished. Therefore, it appears that in the law the position of PAI in schools is very weak because it is not affecting class progress. It is still given the freedom for students to participate or not in PAI lessons.

The relatively loud debate was when Law No. 4 in 1950 was still in the form of designs, including from Aceh. In a meeting of the Workers' Agency of the Central Indonesian National Committee (BP KNIP) on 18 October 1949, Zainal Abidin Achmad as a member had delivered "Aceh Memorandum" (Soebahar, 2013). Aceh Memorandum regarding the memorandum which had previously been submitted included the Minister of Religion's memorandum and Muhammad Syafi'i' (Sumatra Memorandum) on PA which was not made compulsory subjects in schools opposed by the Acehnese people. The memorandum signed by Tengku Muhammad Daud Beureuh as the leader in Aceh was addressed to the chairperson of BP KNIP in Yogyakarta on 16 October 1949, which was stated among other things:

First, religious education should be required subjects (verplichtleervak); secondly, religious schools are recognized as teaching government schools; third, religious schools 
are respected as government schools; fourth, in terms of mixing male and female students (co-education ), it should not conflict with religious feelings with local customs in Sumatra.

The above law is an attempt to fulfill the BP-KNIP recommendation of 17 December 1945 , which demands the renewal of education and teaching in Indonesia. One of the recommendations concerns religious education, which is as follows:

Religious teaching should be given a well-organized place so that it gets sufficient attention properly by not reducing the independence of the groups who wish to follow the beliefs they hold. On how to do this, it is good for the ministry to hold negotiations with the workers' bodies. Madrasah and Islamic boarding schools which are essentially one of the ways and sources of education and knowledge of common people who have deep roots in Indonesian society, in general, should also receive real attention and assistance in the form of guidance and material assistance from the government (Maksum, 1999).

Before the enactment of this law, the government had issued several policies on religious education, for example, the first was the Joint Regulation of Minister of Education and Culture Teaching (PP and K) and Minister of Religion No. 1142 /Part A. (teaching) on 2 December 1946 and No. 1285/KJ (Religion) on 2 December 1946. In this regulation, it is stated that religious education is given in low schools since class IV. Even though the law does not regulate education in Madrasah, its contents are quite indicative of the extent to which the government pays attention to education of Madrasah. The better the policy on religious education in schools seems to be more positive in paying attention to Madrasah education as can be observed in subsequent developments (in the new order).

What can be understood of Law No. 4 year 1950 and Law No. 12 year 1954 "about the Fundamentals of Education and Teaching in Schools" is it limited to the regulation of education in schools, but in reality it does not pay enough attention to education outside the schools. In article 2, the law is even stressed that "This Act does not apply to education and teaching in religious schools". Regarding Madrasah only implied in Article 10 Paragraph 2 that studying in a religious school that has received the recognition of the minister of religion is considered to have fulfilled the learning obligation.But in its development, the government's effort to improve the status of Madrasah is to erect private Madrasah that are managed by the community, both in the form of private and organizations (Daulay, 2011).

\section{Teacher Policy}

The Central Committee of National Committee Workers (BPKNP) held talks on the outline of national education on December 27, 1945. The results of these talks formed a special commission to formulate in more detail the outline of education in Indonesia. In a report prepared by the committee, religious education was proposed as follows (Steenbrink, 1986). (a) Religious lessons in all schools, given based on school hours. (b) Teachers are paid by the government. (c) This elementary school education is given starting in class IV. (d) Education is held once a week at certain hours. (e) Teachers are appointed by the department of religion. (f) Religious teachers are also required to be proficient in general education. (g) The government provides books for religious 
education. (h) Training for religious teachers is held. (i) The quality of pesantren (Islamic boarding school) and madrasah (Islamic school) must be improved. (j) Arabic teaching is not required.

Specifically for (f), (h), (i), and (j), it seems intended as an expert education criticism of religious teaching in general. So, the religion teachers during the old order government still did not get too much special attention. Because of several points proposed by BPKNP to the government, it shows that there is still a lack of seriousness from the government in the matter of religious education in schools, especially the teaching staff.

\section{Policy towards Curriculum}

It is very important the efforts made by the Minister of PP and K (Mr. Soewandi) to change the education and teaching system so that it will be more in line with the wishes and ideals of Indonesian people. The formation of the Teaching Inquiry Committee was in the context of changing the colonial education system into a national education system (Ministry of Education and Culture, 1986). As a consequence of the change in the system, the curriculum at all levels of education has also changed, so that which was originally oriented towards colonial interests is now changed in line with the needs of an independent nation.

After the Education and Teaching Law number 4 in 1950 was issued, then: (a) The low education curriculum is intended to prepare children to have the foundations of knowledge, skills, and dexterity both physically and mentally, and develop their talents and preferences. (b) The secondary education curriculum is intended to prepare students for tertiary education, as well as to educate experts in a variety of special fields, according to their talents and community needs. (c) The higher education curriculum is intended to prepare lessons so that they can become leaders in society, and can maintain the progress of science, and the progress of social life.

From the aforementioned Law, we can see and analyze that the Indonesian people need improvement in all aspects of life, namely the physical and mental aspects. So the need for religious studies is considered important although in general, it is not yet comprehensive policies of their application in Indonesia at that time.

\section{Introductory Language in the Learning Process in the Old Order Era}

Rifa'i (2016), states that "Language used in the learning process is Bahasa (Indonesian language). The use of Bahasa as the language of instruction in the teaching and learning process is regulated in chapter IV article 5 of Law No. 4 in 1950, namely: (a) Bahasa as a unifying language is the language of instruction in schools throughout the Republic of Indonesia. (b) In kindergartens and the three lowest classes in low schools, regional languages may be used as the language of instruction.

\section{A Brief History of Upheaval in Indonesia in the Old Order Era}

Communists were usually the keenest to attack the governments of capitalist countries. They said capitalist countries could not create peace and tranquility. Only in the communist government said that they could realize national solidarity and harmony. Only 
communism can end hostilities and create a new age of life-based on eternal peace, which is full of love. They called for harmony and national solidarity under the banner of a communist government, they promised that if all states had a communist ideology, there would be no more hostility in this world, no division (Colarz, 1994).

The first sheet of history of the communist movement in Indonesia began with the arrival of Neevliet (1883-1942), a Dutchman in the Archipelago in 1913. At first, he was a Catholic mystic but turned to revolutionary social democratic ideas. After his arrival, he founded the Indische Social-DemocratischeVereniging or ISDV (United Nations Social Democratic Union), a leftist party that quickly developed into the first communist party in Asia outside the Soviet Union (Samsudin, 2005).

Further development, the influence of the left brought by ISDV into SI (Sarekat Islam) grew larger and caused severe internal conflict and led to the emergence of two factions within the SI body: "Red SI" (Communist) and "SI White" (Follower of Islam). Subsequently, in May 1920, the ISDV which had succeeded in gaining huge support from SI members changed its name to the Communist Union in the Indies and 1924 it was renamed the Indonesian Communist Party (PKI). Since that time, PKI was born and then overshadowed the journey of the Indonesian nation and state for about 42 years (19241966).

The situation which was very dominant in PKI era was the party's infiltration into the National Front institution that was formed with the aim of a way to move the community. Through PKI mass organizations, the National Front institution was finally infiltrated and controlled by the party and was made a PKI mount.

One more thing that helped PKI was the State Document which was used as a guide to run the government. The document was Bung Karno's speech in the context of the Decree of 5 July 1950, concerning returning to 1945 Constitution; the speech was entitled "The Rediscovery of Our Revolution". Bung Karno asked DPA (House of Representatives) that the contents of the speech be used as GBHN (Outline of State Policy). DPA formed a committee and appointed DN Aidit as chairman to carry out Bung Karno's request. The documents produced by the DPA were named the Political Manifesto of the Republic of Indonesia. Its contents, no doubt, are loaded with PKI programs and PKI-style revolution theses. As a state document used to provide direction for development, it is very easy for PKI to dictate its will in all fields of political, economic, socio-cultural, legal, and security state structures.

After carrying out a rebellion and betrayal of Indonesian people, the MPRS/XXV/1966 TAP came out which contained the dissolution of Indonesian Communist Party (PKI), statements as a banned organization in all regions of the Republic of Indonesia for the PKI, and a ban on any activity to spread or develop understanding of the teachings of communism, marxism, and Leninism (Kasemin, 2004).

From the brief description of PKI above, the writer analyzed that PKI developed in the old order era had a considerable effect in all aspects including education, especially on Islamic education. Because in making state policies, it must receive serious attention from PKI political elite, which could one day be a policy that is more open to Islamic education 
which can backfire for the policies made by PKI. After the rebellion by PKI, the process of cleansing communist influence in all parts of Indonesia was carried out, including in education. Islamic education is given more attention after the G30 S/PKI tragedy, making Islamic education a better place of education policy in Indonesia.

\section{Analysis of Islamic Education Policy Theories in the Old Order Era}

In writer's opinion, there are several theories used in the formulation of policies as follows:

\section{Institutional Theory}

The policy formulation of institutional theory simply means that the task of making public policy is the government duty. So, anything the government makes in any way is the public policy (H.A.R \& Nugroho, 2009).

The writer sees that at the time the government, in this case, the policymaker was President Soekarno, whose dictum was passed on to the minister of education and culture and received approval from the DPR (Regional Representative Council) reflected that there was a correlation with institutional theory in which the task of making public policy in the sense education policy was specifically made by the government as an authority according to this theory.

Examples of institutional theories used in making policies towards Islamic education in the old order era are the Joint Regulation of the Minister of PP and $\mathrm{K}$ and the Minister of Religion (No. 1142/Part A. (teaching) on 2 December 1946 and No. 1285/KJ (religion) on 2 December 1946. In this regulation, it is stated that religious education is given in low schools since grade IV.In the regulation, the authority in making policy is the Minister of Religion in the auspices of the Ministry of Religion and the Minister of Education under the auspices of the Ministry of Education.

\section{Process Theory}

In this theory, the followers accept the assumption that politics is an activity that has a process.In writer's opinion, this process theory correlates also with the existing policies regarding the formulation of the old-order Islamic education policy, which can be seen in the process that must be passed by a policy from the policy formulation stage to the next stages. Aceh memorandum, for example, before the policy on education was ratified. This reflects that the policy that will be made requires a process before it is ratified, and after it is implemented it needs more processes such as supervision.

\section{Elite Theory}

This theory develops from an elite-mass political theory that bases itself on the assumption that in every society there must be two groups, namely holders of power or elites and those who do not have power or the masses. This theory develops itself to the fact that no matter how democratic, there is always a bias in policy formulation because ultimately the policies that are born are the political preferences of the elite - no more. 
Like institutional theory, the elite theory provides an overview of policies taken by the wishes of the political elite. This is what colored the old order era, where the policies taken were strongly influenced by the leading political elite, seen in policy towards the department of religion and Islamic tertiary institutions.

\section{Incremental Theory}

This theory explains that in every decision-making it is always endeavored to avoid many problems that must be considered (as in a comprehensive rational theory). At the same time, it is recommended to describe more ways taken by government officials in making daily decisions.

From this explanation, the incremental theory is centered on; (a) the selection of goals or objectives and analyses of the empirical actions needed to achieve them are seen as interrelated rather than as separate, (b) decision-makers are considered to only consider several alternatives directly related to the main problem, while other alternatives are only seen as incremental or marginal when compared to the current policy.

Furthermore, this incremental theory states that; (c) each alternative which only will have fundamental consequences is going to be evaluated, (d) the problems faced by decision-makers will be regularly defined, (e)there are no decisions or the right way to solvefor each problem. So, a good decision lies only in the belief that various analyses will ultimately agree on a particular decision even without agreeing that the decision is the most appropriate as a means to an end, (f) incremental decision-makers are essentially small improvements and this is more directed to correct imperfections of concrete efforts in overcoming existing problems than as an effort to offer completely new goals in the future (Rohman, 2009).

The incremental theory is very appropriate in the use of theory in the old order era. Policies on Islamic education that continued to reform became evidence that Islamic education was increasingly becoming a serious concern by the Indonesian government at that time, especially after the G30 S/PKI incident. Where was the issuance of the 1966 MPR TAP which required religious studies at all levels of education ranging from elementary schools to universities in Indonesia.

\section{CONCLUSION}

During the old order, there were very few policies towards Islamic education, but the policy did not provide a clear status of Islamic education itself in public schools. As a newly independent country, the Unitary State of Republic of Indonesia is just the beginning to carry out democratic activities in the country. So, there are still many shortcomings that occur, including in the field of education in general and the teaching of religion in particular. The dualism inherited from the education system in the Dutch period caused Islamic education as something that was considered not too important to be learned in school because students were considered to have studied at home and in the community in terms of religious knowledge. The era of the old order was also marked by the 
development of communist ideas spread by the Indonesian Communist Party (PKI), which had an enormous influence on the conditions and situation of Indonesian people in all fields. After the rebellion that occurred and the suppression of PKI, Islamic education received serious attention from Indonesian government who needed to make a renewal movement in education to protect the nation's generations from communist ideas that could endanger the sovereignty of Indonesian people.

\section{REFERENCES}

Abdullah, M. A. (2017). Islamic studies in higher education in Indonesia: Challenges, impact and prospects for the world community. Journal of Islamic Studies, 55(2), 391-426. https://doi.org/10.14421/ajis.2017.552.391-426.

Ahmad, J. (2018). Analisis Kebijakan Pendidikan Agama Islam di Sekolah Umum pada Zaman Belanda, Jepang dan Orde Lama. Syarif Hidayatullah State Islamic University Jakarta. https://doi.org/10.13140/RG.2.2.31021.33760.

Ali, N., \& Sumedi. (2010). Analogi Pendidikan Islam. Yogyakarta: Idea Press.

Anderson, J. E. (1979). Public Policy Making. Holt, Rinehart \& Winston.

Colarz, W. (1994). Komunisme dan Kolonialisme. Usaha Nasional.

Daulay, H. P. (2011). Historitas dan Eksistensi “Pesantren, Sekolah dan Madrasah." PT. Tiara Wacana.

Daulay, H. P. (2017). Islamic Education in Indonesia : A Historical Analysis of Development and Dynamics Haidar Putra Daulay Abstract: International Conference the Community Development in ASEAN, 291-307. file:///C:/Users/PC/Downloads/Documents/291_Islamic Education In Indonesia A Historical Analysis.pdf.

Fadli, M. R., \& Kumalasari, D. (2019). Sistem Pendidikan Indonesia Pada Masa Orde Lama (Periode 1945-1966). Agastya: Jurnal Sejarah dan Pembelajarannya, 9(2), 157. https://doi.org/10.25273/ajsp.v9i2.4168.

H.A.R, T., \& Nugroho, R. (2009). Kebijakan Pendidikan "Pengantar untuk Memahami Kebijakan Pendidikan dan Kebijakan Pendidikan Sebagai Kebijakan Publik." Yogyakarta: Pustaka Pelajar.

Irianto, Y. B. (2011). Kebijakan Pembaruan Pendidikan. Jakarta: PT. Rajagrapindo Persada.

Ismail. (2016). Politik Pendidikan Islam Orde Lama 1945-1965 (Study Kebijakan Pemerintah dalam Penyelenggaraan Pendidikan Islam). Journal of Social Community, 1(1), 139-169. http://ejournal.kopertais4.or.id/madura/index.php/kabilah/article/view/1714.

Kasemin, K. (2004). Mendamaikan Sejarah, Analisis Wacana Pencabutan TAP MPRS/XXV/1996. Yogyakarta: LKiS.

Kosim, M. (2014). Kebijakan Pendidikan Agama Islam di Sekolah pada Masa Orde Lama. Karsa, 22(1), 1-20. https://doi.org/http://dx.doi.org/10.19105/karsa.v22i1.550.

Mahfud, C. (2013). Politik Pendidikan Islam di Indonesia (Studi Analisis Kebijakan Pendidikan Islam Pasca Orde Baru). IAIN Sunan Ampel.

Mestoko, S. (1985). Pendidikan di Indonesia dari Zaman ke Zaman. Jakarta: Balai Pustaka. 
Ministry of Education and Culture. (1986). Pendidikan Indonesia dari Jaman ke Jaman. Jakarta: Balai Pustaka.

Muzammil, A. (2016). Kebijakan Pemerintah dalam Bidang Pendidikan dari Orde Lama Sampai Orde Baru. POTENSIA: Jurnal Kependidikan Islam, 2(2), 183. https://doi.org/10.24014/potensia.v2i2.2537.

Nugroho, R. (2008). Kebijakan Pendidikan Yang Unggul. Yogyakarta: Pustaka Pelajar.

Richard, H. (1974). The Study of Public Policy. Bobbs-Merrill.

Rifa'i, M. (2016). Sejarah Pendidikan Nasional: Dari Masa Klasik Hingga Modern. Yogyakarta: Ar-Ruzz Media.

Rohman, A. (2009). Politik Ideologi Pendidikan. Jakarta: Laksbang Mediatama.

Samsudin. (2005). Mengapa G30 S/PKI Gagal? Yogyakarta: Yayasan Pustaka Obor Indonesia.

Soebahar, A. H. (2013). Kebijakan Pendidikan Islam dari Ordonasi Guru Sampai UU Sisdiknas. Jakarta: PT. Rajagrafindo Persada.

Steenbrink, K. A. (1986). Pesantren Madrasah Sekolah Pendidikan Islam dalam Kurun Modern. Bandung: Dharma Aksara Perkasa.

Thomas, D. (1978). Understanding Public Policy. Englewood Cliffs, N.J.: Prentice-Hall.

Yuningsih, H. (2015). Kebijakan Pendidikan Islam Masa Orde Baru. Jurnal Tarbiya, I(1), 175-194.

https://journal.uinsgd.ac.id/index.php/jurnaltarbiya/article/view/142/pdf_8.

Zuairini. (1992). Sejarah Pendidikan Islam di Indonesia. Jakarta: Bumi Aksara. 